\title{
AMALAN PEMBERIAN MAS KAHWIN DAN WANG HANTARAN DALAM KALANGAN MASYARAKAT MELAYU: PERSPEKTIF FIQH DAN UNDANG-UNDANG KELUARGA ISLAM DI MALAYSIA
}

\section{(Dowry and Provision of Gift Money in Malay Community from the Perspective of Islamic Jurisprudence and Islamic Family Law in Malaysia)}

\author{
Ahmad Haziq Haikal Kamal* \\ haziqhaikal1990@gmail.com \\ Miszairi Sitiris \\ miszairi@iium.edu.my
}

Jabatan Fiqh dan Usul Al-Fiqh, Kulliyyah Ilmu Wahyu dan Sains Kemanusiaan, Universiti Islam Antarabangsa Malaysia.

Pengarang koresponden (Corresponding author): *

Rujukan artikel ini (To cite this article): Ahmad Haziq Haikal Kamal \& Miszairi Sitiris. (2022). Amalan pemberian mas kahwin dan wang hantaran dalam kalangan masyarakat Melayu: Perspektif Fiqh dan Undang-undang Keluarga Islam di Malaysia. Kanun: Jurnal Undang-undang Malaysia, 34(1), 141-166. http://doi.org. 10.37052/ kanun.34(1)no7

\begin{tabular}{|llllll|}
\hline $\begin{array}{l}\text { Peroleh: } \\
\text { Received: }\end{array} \quad$ 15/9/2021 & $\begin{array}{l}\text { Semakan: } \\
\text { Revised }\end{array} \quad 27 / 10 / 2021$ & $\begin{array}{l}\text { Terima: } \\
\text { Accepted: 21/12/2021 }\end{array}$ & $\begin{array}{l}\text { Terbit dalam talian: } \\
\text { Published online }\end{array}$ & 2/1/2022 \\
\hline
\end{tabular}

\footnotetext{
Abstrak

Artikel ini meninjau amalan masyarakat Melayu dalam perkahwinan berkaitan dengan pemberian mas kahwin dan wang hantaran yang diberikan oleh suami kepada isterinya. Menurut kebiasaan dalam majlis akad nikah di kebanyakan negeri kadar mas kahwin disebutkan ketika ijab dan kabul, tetapi tidak disebutkan jumlah wang hantaran, walaupun kedua-duanya dicatatkan dalam sijil pernikahan. Pemberian wang hantaran di samping mas kahwin dilihat sebagai dua elemen yang sama dan berbentuk wang, namun berbeza dari sudut penamaannya. Mas kahwin yang wajib diberikan oleh suami kepada isteri adalah 
bersandarkan kepada al-Quran dan al-Sunnah. Pemberian wang hantaran pula merupakan adat dan uruf yang diamalkan oleh masyarakat Melayu semasa perkahwinan. Perbezaan pada sebutan nama menimbulkan persoalan tentang kedudukan dan fungsi sebenar wang hantaran serta kesan hukum terhadap hak dan pemilikannya. Oleh itu, artikel ini bertujuan untuk mengenal pasti dan membincangkan hukum dan kedudukan keduadua pemberian tersebut menurut fiqah dan Undang-Undang Keluarga Islam. Artikel ini memaparkan kajian kepustakaan dengan merujuk penulisan ulama fiqah muktabar dan kajian teks terhadap peruntukan undang-undang yang berkaitan dengan tajuk yang dibincangkan. Hasil kajian mendapati bahawa kurangnya kefahaman dalam memahami hukum mas kahwin dan wang hantaran serta ketidakseragaman rekod butiran perkahwinan dalam sijil nikah membawa kepada salah faham dalam kalangan masyarakat sekali gus memberikan impak dan kesan terhadap hak dan pemilikan kedua-duanya.

Kata kunci: Mas kahwin, wang hantaran, adat, fiqah, Undang-Undang Keluarga Islam, pemilikan

\begin{abstract}
This article explores the Malay community's marriage traditions, namely the distribution of dowry and provision of gift money by the husband to his wife. According to custom, during the marriage ceremony in most states, the dowry rate is mentioned in the ijab and kabul, but the amount of provision of gift money is not mentioned even though both are recorded in the marriage certificate. In addition to dowry, the provision of gift money is viewed as two similar elements, both of which are monetary in nature but have distinct individual names. Dowry is required to be given by the husband to his wife according to the Quran and Sunnah. However, the provision of gift money is a tradition and 'urf in marriage that is practiced by the Malay community. Their differential pronunciations pose concerns about the real status and function of provision of gift money as well as the legal implications for their right and ownership. Therefore, this article aims to pinpoint and discuss the law and the status of both dowry and provision of gift money in accordance with Islamic jurisprudence and Islamic family law. The article employed library research to expound on the writings of jurists of Islamic jurisprudence as well as textual studies on the provisions of law related to the issue concerned. The study found that a lack of understanding of the law governing dowry and provision of gift money, as well as incoherence in the marriage certificate's record of marriage details, have resulted in misunderstandings within the community while also affecting the right and ownership of both gifts.
\end{abstract}


Keywords: Dowry, provision of gift money, tradition, Islamic jurisprudence, Islamic Family Law, ownership

\section{PENDAHULUAN}

Mahar atau mas kahwin ialah pemberian wajib yang diberikan kepada isteri sebagai tanda penghormatan dan kemuliaan terhadapnya ketika menempuh alam perkahwinan. Kewajipan ini merupakan hak isteri berdasarkan Surah al-Nisā ayat empat yang bermaksud: "Dan berikanlah kepada perempuanperempuan itu maskahwin-maskahwin mereka sebagai pemberian yang wajib". Pensyariatan ini mengangkat darjat dan kedudukan seseorang isteri dan merupakan hukum yang terbit daripada hukum akad nikah yang sah.

Di kebanyakan negeri di Malaysia, wang hantaran merupakan adat yang diamalkan oleh masyarakat Melayu yang diberikan oleh suami kepada isterinya dengan sebab berlakunya perkahwinan. Hantaran sering menjadi topik hangat dalam kalangan masyarakat sehingga kadangkala isu mengenainya menjadi tular dan menimbulkan pergaduhan antara kedua-dua belah pihak keluarga (Abdullah, 2016). Amaun yang diminta oleh pihak perempuan dan ketidakmampuan pihak lelaki untuk menyediakannya sering menjadi perbahasan dan perdebatan. Berbeza dengan mas kahwin yang telah ditetapkan kadarnya oleh pihak berkuasa agama, hantaran tiada penentuan khusus bagi menentukan kadar dan jumlahnya. Oleh sebab itu, masyarakat dilihat sering memberikan wang hantaran yang tinggi dalam perkahwinan sehingga ada yang mencecah ribuan ringgit (Ibrahim et al., 2018:535).

Kedua-dua pemberian ini merupakan dua elemen pembayaran yang wujud dalam perkahwinan dan menjadi kewajipan atas suami untuk menyediakannya (Syed Husin, 2017:110). Meskipun suami perlu menyediakan kedua-dua elemen tersebut, kewajipan yang seharusnya dilaksanakan hanyalah pemberian mas kahwin seperti yang telah dilafazkan ketika ijab dan kabul. Pemberian wang hantaran tidak disebutkan secara jelas bersama-sama mas kahwin, namun kedua-duanya direkodkan dalam sijil pernikahan. Perkara ini membawa kepada wujudnya dua pembayaran, namun mempunyai nama serta sandaran hukum yang berbeza. Masyarakat dilihat cenderung untuk melebihkan pemberian wang hantaran berbanding dengan mas kahwin seterusnya mewujudkan kekeliruan dan salah faham tentang hukum dan kedudukan kedua-duanya, bahkan melihatnya sebagai perkara yang wajib dilakukan semasa perkahwinan (Ariffin \& Lubis, 2017:104). Kekeliruan ini memberikan kesan hukum kepada hak dan pemilikan wang hantaran. 
Oleh yang demikian, artikel ini akan mengenal pasti dan membincangkan hukum serta kedudukan mas kahwin dan wang hantaran menurut perspektif fiqah dan Undang-Undang Keluarga Islam serta hukum pemilikannya. Perbincangan ini dimulakan dengan pengertian mas kahwin dan wang hantaran, dalil pensyariatan serta takyif fiqah mengenainya. Perbincangan selanjutnya akan dikhususkan pada peruntukan undang-undang perkahwinan berkaitan dengan mas kahwin dan wang hantaran di negeri-negeri di Malaysia yang meliputi perkara berkaitan dengan pengertian serta hak pemilikan. Seterusnya perbincangan tertumpu pada penetapan mas kahwin dan kedudukan wang hantaran di negeri-negeri di Malaysia serta realiti pengamalannya dalam kalangan masyarakat. Bahagian akhir artikel pula akan memberikan kesimpulan dan cadangan bagi penambahbaikan urusan perkahwinan di Malaysia.

\section{MAS KAHWIN DAN HANTARAN}

\section{Pengertian Mas Kahwin}

Bagi masyarakat Melayu, penggunaan perkataan mas kahwin digunakan secara meluas dan lebih popular berbanding dengan perkataan mahar. Menurut Shafak Ahmad (2012:28), mahar disebut sebagai mas kahwin kerana suatu ketika dahulu emas dijadikan sebagai wang mahar perkahwinan seseorang, dan biji-biji emas itu merupakan mata wang yang digunakan pada masa tersebut. Mas kahwin atau mahar berasal daripada perkataan bahasa Arab yang bermaksud pemberian yang diberikan kepada perempuan dan dijadikan sebagai mahar (Ibn Manzur, 1993). Mahar juga turut mempunyai beberapa nama lain seperti șadāq, niḥlah, farịdah, hibā', 'ajr, țawl, 'uqr, dan 'aläiq, yang merujuk maksud dan pengertian yang hampir sama dengan mahar (al-Khatib al-Syirbini, 1994:367).

Para fuqaha Islam daripada pelbagai aliran mazhab memberikan beberapa takrifan mengenai mahar. Menurut Ibn 'Abidin (1992:101), mahar ialah suatu nama bagi pemberian yang wajib diberikan kepada perempuan dengan sebab pernikahan atau persetubuhan. Ibn 'Arafah (n.d:293) pula menyatakan bahawa mahar diberikan kepada wanita bagi membolehkan beristimta' (berseronok) dengannya. Sementara Ibn Taqiuddin (1994:367) pula mentakrifkan sebagai suatu harta yang wajib diberikan kepada wanita daripada lelaki dengan sebab berlakunya pernikahan atau persetubuhan. Berdasarkan takrifan fuqaha ini, mahar ialah pemberian yang diberikan kerana berlakunya pernikahan atau persetubuhan, namun jika dilihat dari sudut pandang yang berbeza, mahar 
memberikan gambaran tentang usaha dan pengorbanan seorang lelaki bagi menjadikan seorang wanita itu halal baginya.

Mas kahwin disimbolikkan sebagai penzahiran rasa kasih dan sayang seorang suami kepada isterinya. Namun begitu, di Barat, mas kahwin diberikan sebagai tujuan menghalang daripada berlakunya kes penceraian (Hj Muh. Ali \& Hj Azahari, 2013:71). Dengan pemberian pada kadar nilai seperti sebuah kereta dan juga wang tunai (Welchman, 2004:189) secara bertangguh, mampu mengelakkan daripada berlakunya perkara yang tidak diingini seperti memperlakukan isteri dengan sesuka hati atau menceraikannya dengan mudah (Mehdi, 2003:120). Menurut Korson (1967:529) suami perlu menyerahkan keseluruhan mas kahwin dalam jumlah dan kadar yang tinggi kepada isteri sekiranya berlaku penceraian. Oleh itu, amalan meminta mas kahwin yang tinggi dalam kalangan wanita Eropah adalah bertujuan untuk melindungi hubungan rumah tangga mereka.

\section{Definisi Hantaran}

Menurut Ibrahim et al., (2018:537) tradisi memberikan wang hantaran ini merupakan kesan daripada pengaruh dan budaya perkahwinan Hindu dan Buddhayang telahlama bertapak sebelumkedatangan Islamke Tanah Melayu. Amalan seperti pemberian peralatan kecantikan, buah-buahan, barang perhiasan, pakaian serta lain-lain diberikan oleh pengantin lelaki kepada pengantin perempuan. Menurutnya lagi, hantaran merupakan hadiah dalam bentuk wang dan lain-lain yang ditetapkan oleh pihak keluarga perempuan. Hantaran juga dikenali sebagai duit hantaran dan barang hantaran. Dewan Bahasa Dan Pustaka (n.d.) pula mendefinisikan hantaran sebagai barangbarang seperti hadiah yang dibawa bersama-sama dengna wang hantaran oleh pihak pengantin lelaki untuk pengantin perempuan. Menurut Syed Husin (2017:110) hantaran merupakan pemberian yang terdiri daripada dua bentuk, iaitu wang hantaran dan barang hantaran. Hantaran merupakan amalan yang diterima oleh masyarakat dan merupakan pemberian yang terasing daripada mas kahwin. Berdasarkan takrifan tersebut, hantaran yang diberikan adalah terdiri daripada dua bentuk pemberian sama ada berbentuk wang atau barangan iringan seperti yang diminta dan ditentukan jumlahnya oleh pihak pengantin perempuan. Walau bagaimanapun, hanya hantaran berbentuk pemberian wang sahaja yang mempunyai persamaan elemen dengan mas kahwin, iaitu pembayaran sejumlah wang kepada pengantin perempuan semasa upacara akad nikah dan dicatatkan dalam sijil nikah walaupun tidak disebut ketika majlis ijab dan kabul berlangsung. 
Amalan pemberian hantaran ini bukan sahaja diamalkan masyarakat Melayu di Malaysia bahkan turut diamalkan oleh masyarakat di negara Indonesia. Menurut Safitrah (2013:85) masyarakat Muslim di Pulau Bangka, Indonesia, juga turut mengamalkan budaya hantaran yang terdiri daripada barangan, makanan dan juga wang tunai yang lebih dikenali sebagai "pengantar". Menurutnya lagi, meskipun pemberian tersebut tidak diwajibkan, namun pemberian berbentuk wang tunai adalah sesuatu yang dianggap wajib sebagai melengkapkan sesebuah perkahwinan walaupun dengan kadar yang sedikit. Terdapat persamaan yang boleh didapati antara negara Malaysia dan Indonesia, iaitu hantaran disediakan dan diberikan oleh pihak lelaki. Sebaliknya di negara seperti India dan Bangladesh, hantaran atau bayaran perkahwinan disebut sebagai dowry dan pihak perempuan yang perlu menyediakannya serta diberikan kepada pihak lelaki sama ada dalam bentuk wang tunai atau barangan berdasarkan kemampuan pihak perempuan (Syed Husin et al., 2016:31). Menurut Gebremedhin (2002:38) apabila wanita memberikan dowry yang tinggi dan dipersetujui oleh pihak lelaki, maka status wanita tersebut akan dipandang tinggi oleh pihak keluarga lelaki serta masyarakat sekitarnya. Begitu juga sebaliknya apabila dowry yang diberikan adalah rendah, status pengantin perempuan akan dipandang rendah bahkan berkemungkinan akan dianiaya oleh keluarga pengantin lelaki selepas berkahwin (Tripathy, 2000:17). Pemberian dowry yang rendah juga bahkan mengundang rasa tidak puas hati jika keluarga pengantin lelaki tidak bersetuju dengan jumlah yang diberikan sehingga membawa kepada berlakunya tragedi pembunuhan pengantin perempuan (Oldenburg, 2002:30). Pemberian dowry juga diwajibkan mengikut kehendak mutlak keluarga lelaki tanpa perlunya keredaan dan persetujuan daripada pengantin wanita tersebut (Hj Muh. Ali \& Hj Azahari, 2013:70). Berbeza dengan pemberian wang hantaran dowry ialah permintaan melalui persepakatan daripada keluarga pengantin perempuan kepada pihak keluarga lelaki. Jika didapati pihak lelaki tidak bersetuju dengan kadar yang diminta berkemungkinan perkahwinan akan ditunda sehingga keduadua pihak mencapai persepakatan (Hj. Mohd. Shah, 2005:77). Hal ini menunjukkan bahawa meskipun pemberian wang hantaran merupakan adat yang diamalkan dalam perkahwinan, pemberian bukanlah bersifat paksaan tetapi melalui perbincangan dan mushawarah.

\section{Wang Hantaran menurut Perspektif Fiqah}

Oleh sebab wang hantaran merupakan tradisi dan adat masyarakat Melayu, istilah ini tidak tidak pernah dibahaskan oleh para ulama terdahulu. Namun 
begitu, terdapat beberapa istilah yang boleh disandarkan bagi memenuhi pengertian wang hantaran menurut fiqah. Menurut syarak, hadiah boleh diertikan sebagai suatu pemberian yang diberikan oleh seseorang kepada orang yang disukai atau dikasihi sebagai tanda mengeratkan hubungan dan berkasih sayang sesama manusia (al-Nawawi, n.d:370). Perkataan hadiah ini juga turut mempunyai beberapa perkataan yang hampir sama pengertiannya seperti atha', hibah dan sedekah. Meskipun terdapat perbezaan antara perkataan tersebut, para fuqaha mazhab fiqah bersepakat bahawa tiada perbezaan pada perkataan hadiah dan hibah. Perkataan ini merujuk makna yang sama walaupun berbeza lafaz (Said Mansur, 2011:13). Perbezaan istilah yang disebutkan perlu dilihat dari sudut pandang objektif dan tujuan penggunaannya. Sekiranya diberikan kerana mengharapkan balasan dan ganjaran pahala, maka pemberian tersebut ialah sedekah. Sekiranya sebagai penghormatan serta kasih sayang, maka pemberitan tersebut ialah hadiah.

Jika diperhatikan pada amalan pemberian wang hantaran yang diamalkan dalam perkahwinan masyarakat Melayu, pihak pengantin perempuan menerimanya ketika majlis perkahwinan. Oleh itu, wang hantaran yang diberikan merupakan suatu pemberian hadiah berupa sejumlah wang dengan kadar tertentu dan diberikan oleh pihak lelaki kepada pihak pengantin perempuan semasa perkahwinan di samping pemberian mas kahwin. Oleh yang demikian, istilah hadiah merupakan pengertian terdekat dan munasabah bagi menyandarkan hukum kepada wang hantaran.

\section{Sandaran Hukum Wang Hantaran}

Wang hantaran seperti yang disebutkan merupakan tradisi dan adat yang tiada sandaran khusus daripada al-Quran mahupun hadis mengenainya. Namun begitu, wang hantaran merupakan salah satu medium pemberian hadiah yang masih dan berterusan diamalkan oleh masyarakat. Pemberian hadiah merupakan sunah dan amat digalakkan untuk diberikan tanpa terikat dengan masa tertentu mahupun individu tertentu. Bahkan hadiah sunat untuk diberikan kepada sesiapa sahaja tanpa mengira pangkat, umur dan kelayakan seseorang. Terdapat beberapa dalil khusus daripada al-Quran dan sunah tentang pensyariatan hadiah dan hibah yang boleh dijadikan sebagai sandaran bagi wang hantaran. Dalam Surah al-Baqarah ayat 177 yang bermaksud: 
“...Dan mendermanya seseorang akan hartanya sedang ia menyayanginya, - kepada kaum kerabat, dan anak-anak yatim dan orang-orang miskin dan orang yang terlantar dalam perjalanan...”.

Ayat ini merangkumi pemberian yang diberikan kepada mereka yang memerlukan dan selainnya, dan pemberian kepada mereka yang memerlukan merupakan sedekah dan pemberian selainnya merupakan hibah (Al-Khin et al., 2003:104). Dalam Surah al-Māidah ayat 2 menyatakan yang berikut, yang bermaksud:

"Dan hendaklah kamu bertolong-tolongan untuk membuat kebajikan dan bertaqwa, dan janganlah kamu bertolong-tolongan pada melakukan dosa (maksiat) dan pencerobohan".

Ayat ini secara jelas mendorong orang-orang yang beriman untuk saling bantu-membantu sesama mereka dalam erti kata pertolongan dalam perkara kebaikan. Pemberian hadiah merupakan perkara yang dituntut dan digalakkan serta merangkumi pengertian kebaikan. Hal ini dinyatakan dalam Surah al-Nisāa, ayat 1 yang bermaksud:

"Dan bertaqwalah kepada Allah yang kamu selalu meminta dengan menyebut-yebut nama-Nya, serta peliharalah hubungan (silaturrahim) kaum kerabat; kerana sesungguhnya Allah sentiasa memerhati (mengawas) kamu".

Pemberian hadiah merupakan tanda kasih dan sayang serta diutamakan pemberiannya kepada kaum kerabat terdekat sebagai pengerat hubungan seperti perintah untuk memelihara hubungan sesama kaum kerabat yang terkandung dalam ayat tersebut. Berdasarkan nukilan al-Khin et al., (2003:105) pemberian hadiah merupakan amalan yang sangat dituntut dan para fuqaha telah bersepakat tentang galakan memberikan hadiah kerana perbuatan ini merupakan salah satu bentuk pertolongan dan sebagai usaha saling membantu.

Hadis yang diriwayatkan oleh al-Bukhari (1989:208) bahawa Nabi SAW bersabda: "Hendaklah kalian saling memberi hadiah, nescaya kalian akan saling mencintai". Meskipun hadis ini secara jelas tidak menyebut tentang pemberian wang hantaran tetapi merupakan sandaran dalil pemberian hadiah dan hibah. Nas tidak menyebutkan secara khusus tentang bentuk dan sifat hadiah yang boleh diberi. Oleh itu, apa-apa barang 
yang harus di sisi hukum syarak boleh dijadikan sebagai hadiah. Oleh yang demikian, jelaslah bahawa pemberian wang hantaran ini hukumnya sunat dan digalakkan serta dianggap sebagai hadiah daripada seorang suami kepada isterinya.

\section{Takyif Fiqhi Wang Hantaran}

Dinyatakan dalam al-Mughni (Ibn Qudamah, 1968:41):

"Sesiapa yang memberikan sesuatu pemberian kepada yang memerlukan kerana Allah, maka pemberian itu berupa sedekah. Dan sesiapa yang memberikan sesuatu pemberian kepada orang lain untuk mendekatkan diri, berkasih sayang kepadanya, maka ia merupakan hadiah."

Berdasarkan nukilan tersebut, boleh dikatakan bahawa pemberian hadiah, hibah dan sedekah, jika dilakukan dengan tujuan semata-mata kerana Allah SWT, akan diberikan ganjaran pahala dan balasan baik daripada Allah SWT. Sedangkan pemberian wang hantaran yang diamalkan oleh masyarakat Melayu dalam perkahwinan merupakan pemberian daripada suami kepada isterinya yang bertujuan sebagai tanda kasih dan pengerat hubungan, tidak syak lagi bahawa pemberian tersebut merupakan amalan kebaikan. Oleh yang demikian, wang hantaran yang merupakan hadiah terkandung di dalamnya sejumlah wang, diberikan oleh suami kepada isterinya semasa perkahwinan merupakan tambahan pemberian di samping pemberian mas kahwin. Oleh sebab wang hantaran merupakan hadiah, maka amalan pemberiannya amatlah dituntut oleh Islam serta mendapat galakan daripada Rasulullah SAW berdasarkan hadis yang telah dinyatakan.

Meskipun begitu, terdapat pandangan daripada fuqaha Mālikīah (alSowi, n.d:456) yang berpendapat bahawa apa-apa jua pemberian yang diberikan oleh lelaki kepada perempuan sama ada sebelum atau semasa akad nikah dianggap sebagai mas kahwin walaupun pemberian tersebut tidak disyaratkan. Menurut pandangan ini, wang hantaran yang sunat diberikan ketika majlis perkahwinan oleh pihak lelaki kepada pihak perempuan turut dianggap sebagai pemberian wajib mas kahwin. Perubahan wang hantaran menjadi mas kahwin tentunya akan memberikan impak yang besar kepada pengantin perempuan terutamanya apabila melibatkan hak dan pemilikan terhadap mas kahwin. 


\title{
MAS KAHWIN DAN WANG HANTARAN MENURUT UNDANG- UNDANG KELUARGA ISLAM
}

\section{Pengertian Mas kahwin menurut Undang-Undang Keluarga Islam}

Dalam seksyen 2 (1) Tafsiran Enakmen Undang-Undang Keluarga Islam Wilayah Persekutuan (1984), Selangor (2003), Johor (2003), Perak (2004), Pahang (2005) dan Kedah (2008) ada memberikan definisi kepada mas kahwin, iaitu:

\begin{abstract}
Mas kahwin ertinya pembayaran kahwin yang wajib dibayar di bawah Hukum Syarak oleh suami kepada isteri pada masa perkahwinan diakadnikahkan, sama ada berupa wang yang sebenarnya dibayar atau diakui sebagai hutang atau tanpa cagaran, atau berupa sesuatu yang menurut Hukum Syarak, dapat dinilai dengan wang.
\end{abstract}

Tafsiran ini secara jelas menyatakan bahawa mas kahwin merupakan pembayaran yang wajib diberikan di bawah hukum syarak bertepatan dengan yang ditakrifkan oleh para fuqaha. Selain itu, mas kahwin hendaklah diberikan menggunakan harta yang dianggap bernilai di sisi syarak. Syarak tidak membenarkan pemberian harta yang menyalahi syariat seperti arak dan khinzir, darah dan bangkai serta harta yang tidak jelas mengenai sifat dan jumlahnya. Sekiranya diberikannya dalam perkahwinan, maka dianggap tidak sah sebagai mahar. Seksyen 106(2) ada menyatakan pengertian harta seperti yang berikut: "Harta ertinya apaapa jenis harta, alih atau tak alih, dan termasuklah wang"

Pengertian ini menjelaskan bahawa apa-apa jua bentuk harta yang dianggap bernilai oleh syarak sama ada harta yang boleh dialih seperti emas dan wang, atau harta yang tidak boleh alih seperti rumah, maka harta tersebut boleh dijadikan mas kahwin.

\section{Mas kahwin menurut Undang-Undang Keluarga Islam}

Dalam seksyen 21 (1) dan (2) menyatakan:

[(1) Mas kahwin hendaklah biasanya dibayar oleh pihak lelaki atau wakilnya kepada pihak perempuan atau wakilnya di hadapan orang yang mengakadnikahkan perkahwinan itu dan sekurang-kurangnya dua orang saksi lain; 
(2) Pendaftar hendaklah, mengenai tiap-tiap perkahwinan yang hendak didaftarkan olehnya, menentu dan merekodkan-

(a) nilai dan butir-butir lain mas kahwin;

(b) nilai dan butir-butir lain pemberian;

(c) nilai dan butir-butir lain apa-apa bahagian mas kahwin atau pemberian atau kedua- duanya yang telah dijanjikan tetapi tidak dijelaskan pada masa akadnikah itu, dan tarikh yang dijanjikan untuk penjelasan; dan

(d) butir-butir cagaran yang diberi bagi menjelaskan mas kahwin atau pemberian.]

Berdasarkan undang-undang di atas, penyerahan mas kahwin perlu dilakukan di hadapan pegawai yang mengakadnikahkan berserta sekurang-kurangnya dua orang saksi. Pendaftar perkahwinan perlulah merekodkan segala maklumat yang berkaitan tanpa sebarang pengecualian. Kepentingannya adalah untuk mengelakkan berlakunya kesilapan dan salah faham yang mungkin berlaku sekiranya maklumat yang dicatatkan berbeza dengan apa-apa yang berlaku ketika majlis akad. Seseorang lelaki itu hendaklah menyerahkan pembayaran mas kahwin di hadapan pegawai akad nikah. Hal ini memberikan pengertian bahawa mas kahwin itu perlu disebut ketika akad dan diserahkan di hadapan orang yang mengakadnikahkan sekali gus menutup ruang untuk berlakunya mahar mithl dalam masyarakat. Menurut Shafak Ahmad (2012:73) dilakukan hal tersebut bagi mengelakkan mahar mithl menjadi amalan ketika majlis akad yang berkemungkinan besar membawa kepada salah faham dan untuk menjaga kemaslahatan hak wanita.

\section{Pengertian wang hantaran menurut Undang-Undang Keluarga Islam}

Dalam seksyen 2 (1) Tafsiran, Enakmen Undang-Undang Keluarga Islam Wilayah Persekutuan (1984), Selangor (2003), Johor (2003), Perak (2004), Pahang (2005) dan Kedah (2008) tidak menyebut secara jelas tentang wang hantaran namun ada memberikan definisi pemberian, iaitu:

Pemberian ertinya pemberian sama ada dalam bentuk wang atau benda-benda yang diberikan oleh suami kepada isteri pada masa perkahwinan 
Jika diamati tafsiran ini tidak menetapkan pemberian itu sebagai pemberian yang diwajibkan seperti mas kahwin. Maka dapat difahami bahawa hantaran merupakan pilihan pengantin lelaki sama ada ingin memberikannya atau tidak sesuatu pemberian kepada perempuan pada masa perkahwinan. Berdasarkan tafsiran ini juga, pemberian terbahagi kepada dua, iaitu pemberian berbentuk wang dan pemberian berbentuk barangan. Maka dapat difahami bahawa apa-apa jua bentuk pemberian sama ada wang atau barangan boleh dijadikan sebagai pemberian pada masa perkahwinan. Serahan pemberian hendaklah dilakukan pada masa berlakunya perkahwinan. Wang hantaran yang dibincangkan dalam artikel ini, tafsiran pemberian pada seksyen 2 (1) ini tidak menyebutkan secara khusus tentang hadiah namun, boleh difahami pemberian di sini termasuk dalam pengertian hadiah yang diberikan oleh suami kepada isterinya. Meskipun wang hantaran tidak disebutkan secara khusus, ia seolah-olah menepati pembahagian hantaran yang terdiri daripada dua bentuk, iaitu bersifat wang dan berbentuk barangan.

Tafsiran tentang wang hantaran ini pernah disebutkan dalam Undang-Undang Keluarga Islam lama yang telah dimansuhkan dengan menggunakan istilah yang berbeza seperti hantaran, belanja dan belanja hangus. Menurut Enakmen Pentadbiran Agama Islam Pahang (1956) wang hantaran dinamakan sebagai belanja yang bererti bayaran pilihan yang dipersetujui oleh kedua-dua belah pihak semasa pertunangan. Menurut Undang-Undang Pentadbiran Islam Melaka (1959) hantaran ertinya bayaran wajib berdasarkan amalan adat tempatan yang diberikan oleh pengantin lelaki kepada pengantin perempuan pada waktu pernikahan. Undang-Undang Pentadbiran Ugama Islam Perak (1965) pula menyatakan belanja hangus itu sebagai sebahagian daripada wang dan/atau barangbarang yang dijanjikan anatara pihak lelaki dan perempuan yang bertunang yang perlu dijelaskan sebelum bersatu dalam sesuatu perkahwinan. Namun begitu, undang-undang lama ini telah dimansuhkan selepas pengisytiharan perlembagaan Malaysia yang memberikan kuasa kepada negeri-negeri bagi menguruskan hal ehwal berkaitan agama Islam (Sitiris, 2008:25).

\section{Wang hantaran menurut Undang-Undang Keluarga Islam}

Berdasarkan undang-undang dalam seksyen 21 (2), pada halaman 150 hingga 151, menyatakan mengenai pemberian: pada dasarnya kelihatan sama dengan mas kahwin, namun wang hantaran tidak disebutkan ketika akad nikah serta tidak perlu kepada saksi ketika serahannya dibuat. Hal 
ini memberikan pengertian bahawa wang hantaran merupakan suatu pemberian yang berbeza dengan mas kahwin. Pemberian yang diberikan oleh pihak lelaki kepada pengantin perempuan turut dicatatkan dalam sijil nikah bersama-sama dengan maklumat mas kahwin. Perkara ini juga telah menimbulkan persoalan tentang kedudukan sebenar wang hantaran apabila wujudnya dua elemen pembayaran yang sama tetapi berbeza pada tujuan dan namanya. Perbezaan ini memberikan kesan terhadap hak dan pemilikannya.

\section{Hak pemilikan mas kahwin dan wang hantaran menurut Undang- Undang Keluarga Islam}

\section{Pemilikan mas kahwin}

Menurut Hj Muh. Ali \& Hj Azahari, (2013:67) mas kahwin ini ialah sebagai usaha Islam untuk mengangkat kedudukan dan martabat wanita dengan memberikan hak dalam pemilikan dan pengurusan. Pada zaman pra-Islam, wali tidak memberikan hak kepada wanita untuk menguruskan harta apatah lagi untuk memilikinya. Menurut al-Zuhaili (n.d:6799) ittifaq fuqaha menyatakan bahawa mas kahwin itu wajib diberikan sepenuhnya melalui persetubuhan dalam akad nikah yang sah ataupun dengan berlakunya kematian dalam keadaan mas kahwin itu sama ada disebut atau tidak ketika akad nikah. Mas kahwin menjadi hak milik penuh isteri dengan jumlah sepenuhnya sekiranya memenuhi syarat tersebut. Oleh yang demikian, tiada siapa dalam kalangan keluarganya mahupun suami atau bapanya sendiri berhak untuk menggunakan atau mengambil hartanya itu tanpa mendapat keizinannya. Jika tidak berlaku persetubuhan sama ada disebabkan oleh penceraian atau berlaku kematian, maka mas kahwin hanya wajib dibayar separuh daripada nilai yang diberikan oleh suami.

Dalam seksyen 57 Enakmen Undang-Undang Keluarga Islam Wilayah Persekutuan, (1987) hak terhadap mas kahwin, dsb., tidak akan tersentuh, seksyen 59 Enakmen Undang-Undang Keluarga Islam Selangor (2003), Johor (2003), Perak (2004), Pahang (2005) dan Kedah (2008), ada menyebutkan mengenai hak pemilikan wanita yang bercerai:

Tiada apa-apa jua yang terkandung dalam Enakmen ini boleh menyentuh apa-apa hak yang mungkin ada pada seseorang isteri di bawah Hukum Syarak terhadap mas kahwinnya dan pemberian kepadanya atau apa-apa bahagian daripadanya apabila perkahwinannya dibubarkan 
Seksyen ini dengan jelas menyatakan bahawa tiada undang-undang yang terkandung dalam Enakmen yang boleh menyentuh apa-apa jua hak yang mungkin ada bagi isteri yang diceraikan terhadap mas kahwinnya atau pemberian yang diterima. Hal ini menunjukkan bahawa undangundang ini memberikan penghormatan yang tinggi serta memelihara hak harta yang dimiliki oleh seseorang isteri. Namun begitu, seksyen ini juga memerlukan penjelasan lanjut tentang hak yang tidak boleh disentuh oleh Enakmen. Mas kahwin seseorang isteri perlu dikembalikan separuh nilainya sekiranya berlaku penceraian sama ada talak atau kematian tanpa hubungan kelamin. Berdasarkan seksyen 57/59 ini, maka bekas suami tidak mempunyai hak untuk menuntutnya kembali, justeru hal ini memerlukan penerangan dan huraian daripada pihak berkaitan.

Seorang suami dianggap sebagai orang yang berhutang kepada isteri sekiranya bayaran mas kahwin itu masih belum dijelaskannya. Mas kahwin yang merupakan pemberian wajib menurut hukum syarak dan undangundang boleh dituntut oleh isteri kepada suaminya di mahkamah syariah sekiranya terjadi penceraian dan bayaran tersebut masih belum dilunaskan. Merujuk kes (Salma v. Mat Akhir, 1984), si suami telah menceraikan isterinya namun berhutang kepadanya kerana masih terdapat tunggakan mas kahwin yang belum dibayar oleh suami. Kes ini dibawa ke mahkamah syariah dan hakim telah memerintahkan supaya suami membayar sejumlah RM600 sebagai bayaran bagi mas kahwin yang terhutang. Tuntutan mas kahwin dan pemberian pada kes (Siti Zamrah v. Maliki, 1988) pula melihat kepada dakwaan suami yang mendakwa wujudnya perjanjian pemberian daripada isteri bagi memudahkan penceraian namun dinafikan olehnya. Hasil keputusan hakim menyebut bahawa suami perlu membayar tuntutan yang difailkan oleh pihak perempuan setelah menerima sumpah bagi menafikan kewujudan perjanjian. Kes yang sama juga dapat dilihat melalui (Norma@Normek bt. Ghazaliv. Mohd Zain bin Abdullah, 2006) yang menuntut tuntutan mas kahwin sebanyak RM5,000 serta tuntutan lain darpada bekas suaminya di mahkamah rayuan setelah rayuannya di mahkamah tinggi ditolak meskipun telah bersumpah menafikan. Kes yang direkodkan di mahkamah syariah ini jelas menunjukkan bahawa mas kahwin itu ialah hak isteri yang perlu diberikan dan isteri boleh membuat tuntutan sekiranya suami tidak membayarnya.

\section{Pemilikan wang hantaran}

Wang hantaran seperti yang telah dinyatakan merupakan pemberian hadiah berbentuk wang. Oleh yang demikian wang hantaran tertakluk pada hukum 
pemberian hadiah dalam Islam. Pemilikan hadiah ini tidaklah memberikan hak mutlak sepenuhnya seperti mas kahwin kepada isteri. Menurut Azahari et al., (2009:123) wang hantaran bukanlah hak mutlak wanita kerana kerap kali digunakan sebagai belanja perkahwinan. Keluarga pengantin perempuan boleh menggunakan wang hantaran itu tanpa perlu meminta izin daripadanya meskipun wang tersebut diberikan oleh pengantin lelaki sebagai hadiah kepada pengantin perempuan. Perkara ini berpunca daripada salah faham dan kekeliruan ibu bapa keluarga pengantin perempuan yang menganggap wang hantaran ialah pemberian wajib selain mas kahwin seterusnya beranggapan wang hantaran hak milik mereka (Ariffin \& Lubis, 2017:104). Oleh itu, pemberian wang hantaran kepada pengantin perempuan disifatkan sebagai pemberian yang tidak memberikan manfaat pemilikan kepadanya. Pun begitu, sekiranya berlaku penceraian, wang hantaran ini tidak boleh dituntut oleh bekas suami berdasarkan pandangan majoriti fuqaha yang berpendapat bahawa apa-apa jua pemberian hadiah sama ada yang diberikan oleh suami kepada isterinya ataupun sebaliknya tidak boleh diminta kembali (Said Mansur, 2011:83).

Pemberian yang telah diserahkan dan diterima merupakan hak milik penerimanya, oleh itu tidak dibenarkan untuk si pemberi meminta kembali pemberiannya melainkan pemberian seorang bapa kepada anaknya. Dalam situasi wang hantaran yang telah diberikan kepada isteri, maka suami tidak berhak menuntutnya kembali sekiranya berlaku penceraian. Namun begitu, sekiranya berlaku penceraian atau fasakh sebelum berlaku hubungan kelamin dan wang hantaran tersebut belum lagi diserahkan, maka isteri tidak berhak menuntut wang hantaran tersebut. Pemberian itu dianggap masih belum sempurna pada rukun dan syarat pemilikannya kerana wang hantaran masih lagi hak milik suami. Apabila berlakunya serahan kepada penerima dan telah sempurna syarat dan rukun, maka suami tidak berhak untuk menuntut kembali walaupun telah bercerai tanpa berlakunya hubungan kelamin kerana status wang hantaran dianggap sebagai hadiah dan bukannya seperti pemberian mas kahwin.

Melihat kepada enakmen Undang-Undang Keluarga Islam di kebanyakan negeri, didapati bahawa tidak dinyatakan secara khusus tentang hak pemilikan terhadap wang hantaran. Namun begitu, seksyen $57 / 59$ boleh diguna pakai untuk menuntut kembali pemberian tersebut kerana wang hatnaran termasuk di bawah pengertian pemberian menurut seksyen 2(1). Seseorang isteri yang telah bercerai boleh membuat tuntutan di mahkamah sekiranya suami tidak melunaskannya sepanjang perkahwinan. Walaupun tiada kes yang direkodkan di mahkamah berkenaan dengan tuntutan wang 
hantaran selepas perkahwinan, kes tuntutan mas kahwin di bawah seksyen 57/59 ini boleh dijadikan contoh dan rujukan dalam hal pemilikan hak yang sepatutnya diterima oleh isteri. Oleh itu, seseorang isteri yang telah bercerai berhak menuntut pemberian tersebut di mahkamah jika pihak suami gagal atau enggan memberikan pemberian yang telah dijanjikannya.

Namun begitu, timbul persoalan adakah isteri berhak menuntut penceraian atau fasakh sekiranya suami gagal memberikan wang hantaran yang telah dijanjikan. Berdasarkan kepada peruntukan di bawah sekyen 52. Perintah untuk membubarkan perkahwinan atau untuk fasakh, Undang-Undang Keluarga Islam Wilayah Persekutuan (1987), seksyen 53 Enakmen Undang-Undang Keluarga Islam Selangor (2003), Johor (2003), Perak (2004), Pahang (2005) dan Kedah (2008), terdapat beberapa alasan yang diterima pakai oleh mahkamah Syariah bagi memerintahkan untuk membubarkan perkahwinan atau untuk fasakh seperti dalam keterangan pada seksyen 52/53, iaitu senarai (a) hingga (1) di dalamnya. Selepas diteliti keterangan pada seksyen 52/53 ini, tiada sebarang sebab munasabah menurut hukum syarak untuk seseorang isteri itu menuntut penceraian disebabkan kegagalan pihak suami memberikan wang hantaran perkahwinan. Oleh itu, berdasarkan peruntukan di bawah seksyen ini seseorang isteri itu tidak berhak menuntut fasakh disebabkan kegagalan atau keengganan suami menyerah wang hantaran. Pun begitu, si isteri berhak untuk membuat tuntuan berdasarkan seksyen 57/59 sekiranya telah bercerai dan terdapat pembayaran yang belum dilunaskan oleh suami sepanjang perkahwinannya.

\section{PENETAPAN MAS KAHWIN DAN KEDUDUKAN WANG HANTARAN NEGERI-NEGERI DI MALAYSIA}

\section{Penetapan mas kahwin negeri-negeri di Malaysia}

Oleh sebab mas kahwin merupakan urusan yang berkaitan dengan hal ehwal agama Islam, penetapannya tertakluk pada bidang kuasa negeri. Oleh itu, didapati kebanyakan negeri telah menetapkan kadar bagi pemberian mas kahwin (Mohammad Syamin, 2012:73-74), dinyatakan seperti Jadual 1.

Penetapan mas kahwin yang dibuat oleh kebanyakan negeri merupakan kadar yang perlu disediakan oleh pengantin lelaki ketika majlis perkahwinan dan tidak boleh diberikan kurang daripada nilai yang ditetapkan. Pada Jadual 1, nilai mas kahwin tertinggi di Selangor adalah pada kadar RM300 sedangkan kadar yang terendah adalah pada RM22.50 di Johor dan Pahang, suatu kadar 
Jadual 1 Kadar mas kahwin kebanyakan negeri di Malaysia.

\begin{tabular}{|l|c|c|}
\hline Negeri & Kadar Mas Kahwin Dara & Kadar Mas Kahwin Janda \\
\hline Johor & RM22.50 & RM22.50 \\
\hline Kuala Lumpur & RM80 & RM40 \\
\hline Selangor & RM300 & RM300 \\
\hline Perak & RM101 & RM101 \\
\hline Kedah & Tidak menetapkan & Tidak menetapkan \\
\hline Pahang & RM22.50 & RM22.50 \\
\hline
\end{tabular}

pemberian yang sangat rendah. Di sisi yang lain, terdapat perbezaan antara kadar perempuan dara dan janda. Sebahagian negeri meletakkan kadar yang rendah kepada taraf janda berbanding dara. Meskipun perbezaan hanya pada tarafnya, tidak seharusnya mas kahwin dibezakan hanya kerana bukan dara. Di negeri Selangor, fatwa telah dikeluarkan dan diwartakan di bawah Enakmen Pentadbiran Agama Islam Negeri Selangor (2003) pada 1 Januari 2010, iaitu:

Menetapkan had minima kadar nilai Maskahwin sebanyak RM300 bagi anak dara atau janda tanpa ada had maksima. Sekiranya terdapat wang hantaran daripada pihak lelaki, ianya dikira sebagai Maskahwin.

Berikutan itu bermula pada tahun 2010 kadar mas kahwin di Selangor telah meningkat sebanyak RM220 bagi anak dara dan sebanyak RM260 bagi janda. Sebelum itu pada kadar mas kahwin ialah RM80 dan RM40. Perbezaan tersebut boleh dilihat pada Jadual 2.

Peningkatan sebanyak sejumlah RM220 dan RM260 ini dilihat sebagai usaha untuk memartabatkan kedudukan kaum wanita di negeri Selangor (Othman, 2009). Namun begitu, meskipun berlakunya peningkatan terhadap kadar mas kahwin tersebut, pelaksanaannya masih dilihat sebagai tidak dapat memartabatkan kedudukan kaum wanita memandangkan jumlahnya yang

Jadual 2 Kadar mas kahwin di negeri Selangor.

\begin{tabular}{|l|c|c|}
\hline \multicolumn{1}{|c|}{ Tahun } & Anak Dara & Janda \\
\hline Sebelum 2010 & RM80 & RM40 \\
\hline Bermula 2010 & RM300 & RM300 \\
\hline
\end{tabular}


Jadual 3 Kadar wang hantaran di Malaysia.

\begin{tabular}{|l|c|c|}
\hline Taraf Pendidikan & Minimum & Maksimum \\
\hline UPSR dan PMR & RM2,000 & RM4,000 \\
\hline SPM & RM4,000 & RM8,000 \\
\hline STPM dan DIPLOMA & RM8,000 & RM12,000 \\
\hline IJAZAH & RM12,000 & RM15,000 \\
\hline IJAZAH SARJANA & RM15,000 & RM20,000 \\
\hline IJAZAH KEDOKTORAN & RM20,000 & RM30,000 \\
\hline
\end{tabular}

terlalu kecil dan sedikit. Penetapan nilai mas kahwin pada had minimum sebanyak RM300 ini dilihat sebagai tidak wajar apabila pemberian wang hantaran lebih tinggi. Pemberian wang hantaran dapat dilihat menerusi kajian khusus oleh Raihanah et al. (2009:124) yang mendapati bahawa pemberian wang hantaran adalah berdasarkan taraf pendidikan seseorang bagi penentuan kadarnya dalam sesebuah perkahwinan. Semakin tinggi taraf pendidikan bakal isteri, semakin tinggi kadar wang hantaran yang diminta. Menurut Ariffin \& Lubis, (2017:110) tidaklah menjadi sesuatu yang pelik tentang kadar wang hantaran apabila terdapat akhbar di Malaysia yang merumuskan kadarnya mengikut taraf pendidikan individu seperti dalam Jadual 3.

Jika kadar minimum mas kahwin merupakan kadar yang paling rendah, iaitu sebanyak RM22.50, bagi wang hantaran pula kadar yang paling rendah sebanyak RM2,000 yang secara jelas menunjukkan bahawa pemberian wang hantaran dilihat sebagai mengutamakan adat. Hal ini kerana amalan masyarakat yang secara kebiasaannya menggunakan wang hantaran sebagai belanja perkahwinan untuk mengadakan kenduri kahwin (Syed Husin et al., 2016:110). Melihat kepada hal ini, masyarakat hanya membayar kadar mas kahwin yang telah ditetapkan memandangkan mas kahwin merupakan ritual wajib sekadar untuk memenuhi keperluan prosedur perkahwinan. Lanjutan itu, mas kahwin yang diberikan kepada pengantin perempuan mendorong kepada pemberian wang hantaran yang tinggi. Menurut Sitiris (2008:191) penetapan had minimum ini dibuat bagi mengimbangi kadar wang hantaran agar pemberiannya tidak menjadi beban kepada para lelaki serta mengelakkan berlakunya nilai yang melampau pada mas kahwin. Namun begitu, realiti yang berlaku, kadar wang hantaran itu sendiri mencapai sehingga puluhan ribu ringgit berbanding dengan mas kahwin. Keadaan yang berlaku ini dilihat melebihkan adat berbanding dengan syariat. 


\section{Kedudukan Wang Hantaran Negeri-negeri di Malaysia}

Wang hantaran menurut masyarakat Melayu adalah berbeza dengan pemberian. Pemberian merupakan pilihan dan kebiasaannya terdiri daripada gelang, rantai dan cincin yang diberikan oleh lelaki kepada isterinya sebagai tanda kesungguhannya dalam perkahwinan. Wang hantaran pula ialah pemberian berbentuk permintaan yang hanya terdiri daripada sejumlah wang diberikan kepada pihak perempuan setelah berbincang tentang kadar yang selayaknya baginya. Oleh itu, menurut Ariffin \& Lubis (2017:104) timbul satu kefahaman yang salah dalam masyarakat yang menganggap wang hantaran ialah pemberian wajib selain mas kahwin. Mereka berpandangan bahawa mas kahwin, pemberian dan wang hantaran merupakan pemberian yang berbeza. Pandangan ini mempunyai asasnya apabila diteliti pada sijil nikah yang dikeluarkan oleh pejabat agama yang mengandungi ketidakseragaman pada butiran perkahwinan. Ketidakseragaman ini menimbulkan kekeliruan dalam masyarakat Melayu tentang status wang hantaran dalam perkahwinan. Wujudnya kolum pemberian dan hantaran dalam sijil nikah seolah-olah menjadikan hantaran itu pemberian yang berbeza dengan pemberian yang disebut dalam enakmen keluarga Islam. Oleh itu, didapati ada sesetengah pasangan yang meletakkan kolum pemberian seperti cincin dan meletakkan amaun duit pada kolum hantaran. Ada pula yang menyatukan cincin dan

Jadual 4 Ringkasan butiran perkahwinan sijil nikah negeri-negeri.

\begin{tabular}{|l|l|}
\hline Negeri & Butiran Perkahwinan \\
\hline Kedah & $\begin{array}{l}\text { I. } \text { Mas kahwin } \\
\text { II. Pemberian }\end{array}$ \\
\hline Perak & $\begin{array}{l}\text { I. Mas kahwin } \\
\text { II. Pemberian lain } \\
\text { III. Hantaran }\end{array}$ \\
\hline Selangor & $\begin{array}{l}\text { I. Mas kahwin } \\
\text { II. Belanja hantaran } \\
\text { III. Pemberian lain }\end{array}$ \\
\hline Pahang & $\begin{array}{l}\text { I. Mas kahwin } \\
\text { II. Hantaran } \\
\text { III. Pemberian lain }\end{array}$ \\
\hline Johor & $\begin{array}{l}\text { I. Mas kahwin } \\
\text { II. Hantaran/Pemberian }\end{array}$ \\
\hline
\end{tabular}


wang hantaran pada kolum pemberian. Dinyatakan dalam Jadual 4 perbezaan berdasarkan negeri mengenai butiran perkahwinan.

Kewujudan dua elemen pembayaran, iaitu pada mas kahwin dan wang hantaran telah menimbulkan persoalan tentang wujudnya dua bentuk bayaran yang sama akan tetapi dikelaskan mengikut nama yang berbeza. Perbezaan ini menghasilkan kesan hukum yang tidak sama serta memberikan impak kepada hak pemilikan wang hantaran. Selain itu, kewujudan mas kahwin dan wang hantaran dalam perkahwinan ini membawa kepada ketidakseimbangan kadar pemberian kedua-duanya apabila pemberian wang hantaran melebihi pemberian mas kahwin.

Masyarakat yang memahami pengertian di sebalik konsep mas kahwin dan kedudukan wang hantaran dengan pandangan yang berbeza. Mereka dilihat terkeliru dengan konsep wang hantaran yang dianggap sebagai wajib seperti mas kahwin. Selain itu, mereka melihat pemberian dengan wang hantaran ketika perkahwinan sebagai dua elemen yang berbeza walaupun pada dasarnya wang hantaran merupakan sebahagian daripada pemberian yang berbentuk wang. Dua elemen yang sama pada nama namun berbeza pada tujuan dan hukum telah mengakibatkan salah faham sehingga boleh mengakibatkan perbalahan antara pihak pengantin lelaki dan pengantin perempuan. Menurut Abdul Rahman, (2007:1) adat hantaran ekstrem sehingga mencecah belasan ribu ringgit bahkan sehingga puluhan ribu ringgit dilihat sebagai penyebab berlakunya pelbagai masalah sosial dalam masyarakat. Tambahnya lagi, hantaran yang tinggi ini juga menyebabkan ada pasangan yang mendesak supaya berhutang demi memenuhi adat perkahwinan tersebut. Kolum yang memisahkan ruangan antara mas kahwin, pemberian dan wang hantaran telah memberikan kesan terhadap kepercayaan dan pegangan masyarakat Melayu yang menganggap bahawa wang hantaran juga merupakan pemberian yang wajib seperti mas kahwin. Sijil nikah yang membezakan antara ketiga-tiga pemberian menggambarkan adat Melayu tersebut diterima dan direkodkan dalam sijil rasmi perkahwinan.

Di sisi yang lain, undang-undang baharu tentang wang hantaran yang telah dikuatkuasakan di Selangor ini telah menafikan kedudukan wang hantaran apabila dianggap sebagai mas kahwin. Oleh itu, mana-mana pemberian wang hantaran yang ada ketika perkahwinan dihukumkan sebagai mas kahwin. Undang-undang ini dilihat mampu memperbaik urusan perkahwinan di negeri tersebut memandangkan masyarakat seringkali menggunakannya sebagai belanja perkahwinan sedangkan wang hantaran diberikan oleh pengantin lelaki kepada pengantin perempuan. Hal ini juga dapat menjamin hak pemilikan yang sepatutnya diterima oleh 
pengantin perempuan dan mengelakkan berlakunya salah faham. Namun begitu, menurut hemat penulis undang-undang ini masih belum kukuh dan menyeluruh penyampaiannya dalam kalangan masyarakat. Meskipun sudah berkuat kuasa sejak tahun 2010, sehingga kini masih terdapat kolum bagi bahagian belanja hantaran walaupun sudah tidak dinyatakan jumlahnya. Perkara ini dilihat sebagai bertentangan apabila undang-undang yang telah dikuatkuasakan tidak dilaksanakan. Hal ini secara tidak langsung memberikan isyarat bahawa wang hantaran itu masih diterima untuk direkodkan membuatkan masyarakat terus percaya dengan kewajipan memberikan wang hantaran kepada perempuan. Oleh itu, perlunya suatu keseragaman dan perubahan dalam pelaksanaan catatan sijil nikah oleh pihak berkuasa agama.

Pemisahan dan pembahagian yang berlaku antara mas kahwin dan wang hantaran dilihat sebagai tidak menjamin hak pemilikan bagi wanita memandangkan wang hantaran bukanlah milik eksklusif seperti mas kahwin. Hal ini disebabkan kedudukan wang hantaran yang dianggap sebagai hadiah dan wajib menurut adat, namun tidak menjadi wajib menurut syariat, mendorong keluarga pengantin perempuan menggunakannya sebagai persiapan bagi membiayai kos untuk melangsungkan walimah tanpa memerlukan izin daripadanya. Sudah menjadi amalan kebiasaan apabila wang hantaran yang diberikan digunakan bagi menampung biaya pengurusan kenduri perkahwinan (Azahari et al., 2009:123). Namun begitu, hal akan menjadi berbeza sekiranya wang hantaran disatukan bersama-sama dengan mas kahwin. Maka tiada siapa yang berhak atasnya melainkan dirinya (pengantin perempuan), selain mempunyai kuasa untuk memiliki harta dan menguruskannya. Sekiranya berlaku perpisahan antara kedua-dua pasangan, penetapan wang hantaran sebagai mas kahwin akan memberikan keuntungan kepada isteri. Seseorang wanita yang diceraikan sama ada secara talak atau kematian berhak untuk memiliki keseluruhan mas kahwinnya. Sekiranya tidak berlaku hubungan suami isteri, maka ia berhak terhadap sebahagiannya. Sebagai contoh jika mas kahwin dicampur bersama-sama dengan wang hantaran sejumlah RM12,000, maka isteri berhak untuk mendapatkan sebahagian itu, iaitu sebanyak RM6,000. Jumlah yang besar dan memberikan ketenangan kepadanya setelah melalui kedukaan dalam penceraian. Berbeza pula sekiranya mas kahwin pada had RM22.50, maka isteri hanya akan mendapat sebanyak sejumlah RM11.25 sahaja. Oleh itu, hak pemilikan terhadap wang hantaran ini sangat penting kepada mereka untuk menjamin hak yang sepatutnya diterimanya. Seharusnya penetapan kadar mas kahwin pada nilai tertentu dan pemberian wang hantaran bersama- 
sama dengan mas kahwin ini dikaji semula oleh pihak berkuasa agama bagi memperbaik urusan perkahwinan di Malaysia.

\section{KESIMPULAN}

Dua pemberian yang sama dalam perkahwinan namun berbeza nama telah menghasilkan kesan hukum yang berbeza dan mendorong salah faham dalam kalangan masyarakat tentang fungsi dan hukum kedua-dua pemberian tersebut. Meskipun wang hantaran adalah sunat diberikan, namun secara realiti masyarakat menganggapnya sebagai pemberian wajib seperti mas kahwin. Hal ini dilihat tidak selari dengan pandangan syarak. Pemberian mas kahwin yang sedikit berbanding dengan wang hantaran dilihat mendahulukan adat berbanding dengan syariat selain mendorong permintaan amaun yang tinggi pada wang hantaran. Penetapan had minimum seperti yang berlaku di negeri Selangor dan negeri lain perlu dikaji semula dengan meletakkan suatu jumlah yang munasabah untuk meraikan situasi dan keadaan ekonomi semasa.

Undang-Undang Keluarga Islam pada kebanyakan negeri yang meletakkan satu seksyen khusus berkaitan dengan mas kahwin dan pemberian adalah untuk menjamin hak tersebut diberikan kepada isteri. Namun begitu, ketidakseragaman yang terdapat pada pemberian dan hantaran di samping mas kahwin dalam sijil nikah seolah-olah menyatakannya sebagai dua perkara yang berbeza. Oleh itu, pemberian hantaran dilihat membawa kepada salah faham dalam masyarakat apabila harta yang sepatutnya menjadi hak milik pengantin perempuan digunakan untuk membiayai majlis perkahwinan. Oleh itu, dicadangkan kepada pihak berkuasa agama supaya kolum wang hantaran dihapuskan dalam sijil nikah dan diletakkan bersama-sama dengan kolum mas kahwin. Dengan terhapusnya wang hantaran dalam sijil nikah dan disatukan pemberiannya bersama-sama dengan mas kahwin dilihat dapat menjamin hak dan manfaat pemilikan serta pengurusan harta kepada isteri. Suatu ketetapan perlulah dilaksanakan dengan menggabungkan wang hantaran bersama-sama dengan mas kahwin ketika ijab dan kabul. Cadangan ini dilontarkan bagi menimbulkan kesedaran dalam kalangan masyarakat serta memperbaik dan mengislahkan urusan perkahwinan agar menjadi lebih baik supaya pemberian mas kahwin itu dilihat betul-betul mengangkat martabat dan kemuliaan para wanita. 


\section{RUJUKAN}

Abdul Rahman, Z. (2007). Mahar in Malaysia: The Law Revisited. Malayan Law Journal Sdn. Bhd.

Abdullah, M. (2016, March 28). Ditumbuk kerana gagal sedia hantaran: Melayu terlalu agungkan adat. Astro Awani. Diakses pada Oktober 24, 2021 daripada https:/www.astroawani.com/gaya-hidup/ditumbuk-kerana-gagal-sediahantaran-melayu-terlalu-agungkan-adat-100130

Akta Undang-Undang Keluarga Islam Wilayah Persekutuan, Tafsiran 2(1), Mas kahwin dan pemberian 21(1)(2), Perintah untuk membubarkan perkahwinan atau untuk fasakh 53, Hak terhadap mas kahwin, dsb. tidak akan disentuh 57 (1984). http://www2.esyariah.gov.my/esyariah/mal/portalv1/enakmen/ Federal_Original.nsf/b3ac9c218c8efdc4482568310022d8b3/d441586f0bd6 767348256cef00297264?OpenDocument

Al-Bukhari, M. I. (1989). Al-Adāb al-Mufrad (M. F. Abd Al-Baqi, Ed.; 3rd ed.). Dar Al-Bashair Al-Islamiah.

Al-Khatib Al-Syirbini, M. (1994). Mughnī al-Muhtāj Ilā Ma rifatī Ma'ān̄̄ Alfāz al-Minhāj (1st ed., Vol. 4). Dar Al-Kutub Al-Ilmiah.

Al-Khin, M., Al- Bugha, M., \& Al-Sharbaji, A. (2003). Al-Fiqh al-Manhajī 'Alā Mazhab al-Imām al-Shāfi' $\bar{\imath}$ (14th ed., Vol. 2). Dar Al-Qalam.

Al-Nawawi, M. S. (n.d.). Al-Majmū' Sharh al-Muhazzab (Vol. 16). Dar Al-Fikr.

Al-Sowi, A. M. (n.d.). Hāshiah al-Sowì 'Alā al-Sharh al-Șaghīr (Vol. 2). Dar Al-Maarif.

Al-Zuhaili, W. (n.d.). Al-Fiqh al-Islāmı̄ Wa Adillatuh (12th ed., Vol. 9). Dar AlFikr.

Ariffin, A. H., \& Lubis, M. A. (2017, May). Mahar Dan Wang Hantaran Dalam Islam: Pemahaman Budaya Melayu Masa Kini. Proceeding of the 10TH International Workshop and Conference of Asean Studies in Islamic and Arabic Education and Educational Science and Technology 2017, 103-113.

Azahari, R., Saripudin, K. N., \& Abd Wahab, R. (2009). Hubungan di antara faktor demografi dengan penentuan kadar hantaran: Kajian di Perlis, Kedah, Pulau Pinang dan Perak. Jurnal Fiqh, 6(1), 107-124. https://doi.org/10.22452/fiqh. vol6nol.6

Dewan Bahasa Dan Pustaka. (n.d.). Hantaran. Pusat Rujukan Persuratan Melayu. Diakses Januari 9, 2021, diambil dari http://prpm.dbp.gov.my/ caril?keyword=hantaran

Enakmen Pentadbiran Agama Islam (Negeri Selangor), Kuasa Jawatankuasa fatwa untuk menyediakan fatwa 47 (2003). https://www.muftiselangor.gov. my/awam/fatwa/fatwa-terkini/186-hukum-penetapan-kadar-maskahwinbagi-negeri-selangor

Enakmen Undang-Undang Keluarga Islam Kedah, Tafsiran 2(1), Mas kahwin dan pemberian 21(1)(2), Hak terhadap mas kahwin, dsb. tidak akan disentuh 
59, Kuasa bagi Mahkamah membatalkan dan menahan perpindahan yang bermaksud untuk mengecewakan tuntutan nafkah 106(2) (2008). http:// www2.esyariah.gov.my/esyariah/mal/portalv1/enakmen/State Enact Ori. nsf/f831ccddd195843f48256fc600141e84/ccf121f01d91d01e4825752b0030 6c85?OpenDocument

Enakmen Undang-Undang Keluarga Islam Negeri Johor, Tafsiran 2(1), Mas kahwin dan pemberian 21(1)(2), Perintah untuk membubarkan perkahwinan atau untuk fasakh 52, Hak terhadap mas kahwin, dsb. tidak akan disentuh 59, Kuasa bagi Mahkamah membatalkan dan menahan perpindahan yang bermaksud untuk mengecewakan tuntutan nafkah 106(2) (2003). http:// www2.esyariah.gov.my/esyariah/mal/portalv1/enakmen/State_Enact_Ori.ns f/100ae747c72508e748256faa00188094/b7b0a4048ca7fac448257118002ea 322? OpenDocument

Enakmen Undang-Undang Keluarga Islam Negeri Selangor, Tafsiran 2(1), Mas kahwin dan pemberian 21(1)(2), Perintah untuk membubarkan perkahwinan atau untuk fasakh 52, Hak terhadap mas kahwin, dsb. tidak akan disentuh 59, Kuasa bagi Mahkamah membatalkan dan menahan perpindahan yang bermaksud untuk mengecewakan tuntutan nafkah 106(2) (2003). http:// www2.esyariah.gov.my/esyariah/mal/portalv1/enakmen/State_Enact_Ori.ns f/100ae747c72508e748256faa00188094/df4d61294a803ada482570ff002bc 369? OpenDocument

Enakmen Undang-Undang Keluarga Islam Pahang, Tafsiran 2(1), Mas kahwin dan pemberian 21(1)(2), Perintah untuk membubarkan perkahwinan atau untuk fasakh 52, Hak terhadap mas kahwin, dsb. tidak akan disentuh 59, Kuasa bagi Mahkamah membatalkan dan menahan perpindahan yang bermaksud untuk mengecewakan tuntutan nafkah 106(2) (2005). http://www2.esyariah.gov. $\mathrm{my} / \mathrm{esyariah} / \mathrm{mal} / \mathrm{portalv} 1 / \mathrm{enakmen} / \mathrm{State}$ Enact_Ori.nsf $/ 100 \mathrm{ae} 747 \mathrm{c} 72508 \mathrm{e} 7$ 48256faa00188094/851d2f82c8be850d4825711c00229d49?OpenDocument

Enakmen Undang-Undang Keluarga Islam Perak, Tafsiran 2(1), Mas kahwin dan pemberian 21(1)(2), Perintah untuk membubarkan perkahwinan atau untuk fasakh 52, Hak terhadap mas kahwin, dsb. tidak akan disentuh 59, Kuasa bagi Mahkamah membatalkan dan menahan perpindahan yang bermaksud untuk mengecewakan tuntutan nafkah 106(2) (2004). http://www2.esyariah.gov. my/esyariah/mal/portalv1/enakmen/State_Enact_Ori.nsf/100ae747c72508e 7 48256faa00188094/9e4fd406514c7b284825703f0016ea77?OpenDocument

Gebremedhin, T. G. (2002). Women, tradition and development: A case study of Eritrea. The Red Sea Press.

Hj Muh. Ali, H., \& Hj Azahari, R. (2013). Objektif syariah dalam pemberian mahar. Jurnal Fiqh, 10, 57-76. https://doi.org/10.22452/fiqh.vol10no1.3

Hj. Mohd. Shah, S. (2005). Al-'Arāf al-Malāyuwīyyah F̄̄ Muqaddimah al-Zawāj $F_{\bar{l}}$ Māliziziȳ (Unpublished Master's dissertation). al-Jami'ah al-Islamiyah al-Alamiyah bi- Maliziya. https:// 
lib.iium.edu.my/mom/services/mom/document/getFile/ m0IROLdD37062c2vQ3q5slq66PmzVCPb20060516161635343

Ibn Abidin, M. (1992). Rad al-Muhtāar 'Alā al-Dur al-Mukhtār (2nd ed., Vol. 3). Dar Al-Fikr.

Ibn Arafah, M. (n.d.). Hāsyiah al-Dusūqi 'Alā al-Sharh al-Kabìr (Vol. 2). Dar Al-Fikr.

Ibn Manzur, M. M. (1993). Lisān al-'Arab (3rd ed., Vol. 5). Dar Al-Sadir.

Ibn Qudamah, M. (1968). Al-Mughnī (Vol. 2). Maktabah al-Qahirah.

Ibn Rushd, M. (2004). Bidāyah al-Mujtahid Wa Nihāyah al-Muqtașid (Vol. 3). Dar al-Hadith.

Ibn Taqiuddin, A. B. (1994). Kifāyah al-Akhyār Fū Halli Ghāyah al-Ikhtișār (A. A. H. Al-Baltaji \& M. W. Sulaiman, Eds.; 1st ed.). Dar Al-Khair.

Ibrahim, S. Z., Yama, P., \& Talib, H. (2018, April). Hantaran Kahwin Dalam 'Urf Perkahwinan Melayu: Satu Kajian Dari Sudut Fiqh Kontemporari. E-Prosiding Persidangan Antarabangsa Sains Sosial Dan Kemanusiaan (PASAK 2018), 534-540.

Korson, J.H.(1967). Dower and social class in an urban Muslim community.Journal of Marriage and Family, 29(3), 527-533. https://doi.org/10.2307/349597

Mehdi, R. (2003). Danish law and the practice of mahr among Muslim Pakistanis in Denmark. International Journal of the Sociology of Law, 31(2), 115-129. https://doi.org/10.1016/j.ijs1.2003.02.002

Mohammad Syamin, R. B. (2012). Qaḍayāa al-Mahr Wa Hadāyā F̄̄ Wilāyah Malākā (Master's dissertation). Al-Jami'ah al-Islamiyah al-'Alamiyah biMaliziya.

Nizamuddin Al-Balkhi, L. U. B. R. (1892). Al-Fatāwā al-Hindiah (2nd ed., Vol. 1). Dar Al-Fikr.

Norma@Normekbt.Ghazaliv.MohdZainbinAbdullah,21.03000-099-0006/2005. 92-100 (2006). http://www.esyariah.gov.my/JurnalHukumSearch/htdocs/ jurnalhukumsearch/JurnalHukumSearchDetailsPageBM.jsp?DetailsID=550

Oldenburg, V. T. (2002). Dowry murder: the imperial origins of a cultural crime. Oxford University Press.

Othman, K. (2009, December 10). Mas kahwin Selangor dinaik kepada RM300. Mstar. https://www.mstar.com.my/lokal/semasa/2009/12/10/mas-kahwinselangor-dinaik-kepada-rm300

Safitrah, Y. (2013). Amalan pemberian mahar dan hantaran dalam kalangan masyarakat Islam Pulau Bangka, Indonesia (Unpublished Master's dissertation). Universiti of Malaya. http://studentsrepo.um.edu.my/id/ eprint $/ 5379$

Said Mansur, S. W. (2011). Aḥkām al-Hadīyyah Fī al-Fiqh al-Islāmī (Master's dissertation). An-Najah National University of Palestine. https://scholar. najah.edu/sites/default/files/all-thesis/the_rules_of_gifts_in_islamic_ 
jurisprudence_fiqh.pdf?fbclid=IwAR1IybjbPWxdvPg-W5qUNrykxK0CkjA oON7LnbEYxLaf7cVP6P48GAdMRt0

Salma v. Mat Akhir, 5. 48/82. 161-174 (1984). http://www.esyariah. gov.my/JurnalHukumSearch/htdocs/jurnalhukumsearch/ JurnalHukumSearchDetailsPageBM.jsp?DetailsID=992

Shafak Ahmad, S. N. A. (2012). Amalan penetapan kadar mahar masyarakat Islam Daerah Klang (Unpublished Master's dissertation). University of Malaya. http://studentsrepo.um.edu.my/id/eprint/5288

Sijil nikah negeri Johor

Sijil nikah negeri Kedah

Sijil nikah negeri Pahang

Sijil nikah negeri Perak

Sijil nikah negeri Selangor

Siti Zamrah v. Maliki, 6. 19. 130-135 (1988). http://www.esyariah. gov.my/JurnalHukum Search/htdocs/jurnalhukumsearch/ JurnalHukumSearchDetailsPageBM.jsp?DetailsID=957

Sitiris, M. (2008). al-Ḥuqūq al-Māliah Lil al-Muțallaqah F̄̄ al-Fiqh alIslāmī Wa Qawānīn al-Usrah al-Islāmiah Bi Mālīziyā Namūzajan (Phd). al-Jami'ah al-Islamiyah al-'Alamiyah bi- Maliziya. https://lib.iium.edu.my/mom/services/mom/document/getFile/ cRCxKLDXhoDrjf7z1 poyOBX5cZBikOqw20110621170219781

Syed Husin, S. N. M. (2017). Gelagat perbelanjaan perkahwinan masyarakat Melayu Muslim menurut perspektif syariah ( Tesis Phd. tidak diterbitkan). University of Malaya. http://studentsrepo.um.edu.my/id/eprint/7379

Syed Husin, S. N. M., Hj Azahari, R., \& Ab. Rahman, A. (2016). Perbelanjaan perkahwinan bagi masyarakat Muslim: Analisis literatur. Jurnal Fiqh, 13(2016), 23-56. https://doi.org/10.22452/fiqh.vol13no1.2

Tripathy, P. C. (2000). Contemporary social problem and the law. A.P.H. Publishing.

Undang-Undang Pentadbiran Islam Melaka, Tafsiran 2(1) (1959). http://www2. esyariah.gov.my/esyariah/mal/portalv1/enakmen/Eng_enactment_Ori_lib. nsf/f831ccddd195843f48256fc600141e84/936935170ffea $75 \mathrm{e} 4825752 \mathrm{~b} 0011$ $35 \mathrm{cb}$ ? OpenDocument

Undang-Undang Pentadbiran Ugama Islam Perak, Ma'ana 2(1) (1965). http:// www2.esyariah.gov.my/esyariah/mal/portalv1/enakmen/State_Enact_Ori. nsf/f831ccddd195843f48256fc600141e84/c51659af9b7b93db48257562001 4c477? OpenDocument

Welchman, L. (2004). Women's rights and Islamic family law: Perspectives on reform. Zed Books. 